\title{
Oral pantoprazole for acid suppression in the treatment of patients with Zollinger-Ellison syndrome
}

\author{
Barbara Désir MD, Pierre Poitras MD
}

B Désir, P Poitras. Oral pantoprazole for acid suppression in the treatment of patients with Zollinger-Ellison syndrome. Can J Gastroenterol 2001;15(12):795-798.

BACKGROUND: The management of patients with gastric acid hypersecretion due to gastrinoma, usually recognized as Zollinger-Ellison syndrome (ZES), was radically changed 10 years ago by the use of proton pump inhibitors. Surgical treatment now concentrates on tumour excision, and in the majority of patients, gastrectomy is no longer required to prevent complications of acid hypersecretion that can be managed pharmacologically.

AIMS: To verify the ability of pantoprazole to control gastric acid hypersecretion and the clinical effects of acid hypersecretion in seven patients with documented ZES.

METHODS: Pantoprazole was administered at an initial dose of $80 \mathrm{mg}$ daily for seven days before basal acid output (BAO) was measured at 08:00, ie, $1 \mathrm{~h}$ before the next dose of pantoprazole was normally ingested. A lower $(40 \mathrm{mg})$ or higher $(120 \mathrm{mg}$ or more) dose of pantoprazole was then used to keep the BAO in the therapeutic range (between 0.1 and $10 \mathrm{mmol} / \mathrm{h}$ ) and to control clinical symptoms such as acid-related pain or diarrhea. RESULTS: BAO and clinical symptoms were controlled with pantoprazole $40 \mathrm{mg}$ daily in one patient, $80 \mathrm{mg}$ daily in two patients, $120 \mathrm{mg}$ daily in three patients and $160 \mathrm{mg}$ daily in one patient.
CONCLUSIONS: Pantoprazole was able to control acid hypersecretion in ZES patients when administered in doses between 40 and $160 \mathrm{mg}$ daily. An initial dose of $120 \mathrm{mg}$ given before further titration of the drug regimen appears to be a reasonable therapeutic strategy.

Key Words: Endocrine tumour; Gastric acid secretion; Gastrointestinal hormone; Peptic ulcer; Proton pump inhibitor; Regulatory peptide

\section{Pantoprazole oral pour la suppression acide dans le traitement des patients atteints du syndrome de Zollinger-Ellison}

HISTORIQUE : La prise en charge des patients souffrant d'hypersécrétion d'acide gastrique due à un gastrinome, habituellement appelé syndrome de Zollinger-Ellison (SZE), a radicalement changé il y a dix ans lors de l'avènement des inhibiteurs de la pompe à protons. Le traitement chirurgical se concentre désormais sur l'excision de la tumeur et dans la majorité des cas, la gastrectomie n'est plus nécessaire pour prévenir les complications de l'hypersécrétion acide, désormais justiciable d'un traitement pharmacologique.

BUT : Vérifier la capacité du pantoprazole à maîtriser l'hypersécrétion d'acide gastrique et ses effets chez sept patients souffrant de SZE documenté.

MÉTHODES : Le pantoprazole a été administré à une dose initiale de

Gastroenterology Unit, Centre hospitalier de l'Université de Montréal, Québec, Québec

Correspondence: Dr Pierre Poitras, Centre hospitalier de l'Université de Montréal - Hôpital Saint-Luc, 1058 St-Denis Street, Montréal, Québec

H2X 3J4. Telephone 514-890-8310 ext 35757, fax 514-412-7314, e-mail pierre.poitras@sympatico.ca

Received for publication August 7, 2001. Accepted October 22, 2001 
$80 \mathrm{mg}$ par jour pendant sept jours avant la mesure de la sécrétion acide de base à 8 heures le matin, c'est-à-dire, une heure avant la dose suivante habituelle de pantoprazole. Une dose de pantoprazole inférieure $(40 \mathrm{mg})$ ou supérieure (120 mg ou plus) était alors utilisée pour maintenir la sécrétion acide de base à l'intérieur des valeurs thérapeutiques (soit entre 0,1 et $10 \mathrm{mmol} / \mathrm{h}$ ) et pour maîtriser les symptômes cliniques, tels la douleur et la diarrhée associées à la présence d'acide.

RÉSULTATS : La sécrétion acide de base et les symptômes cliniques ont été maîtrisés au moyen de pantoprazole $40 \mathrm{mg}$ par jour chez un patient, $80 \mathrm{mg}$ par jour chez deux patients, $120 \mathrm{mg}$ par jour chez trois patients et $160 \mathrm{mg}$ par jour chez un patient.

CONCLUSION : Le pantoprazole a permis de maitriser l'hypersécrétion acide chez les patients atteints de SZE lorsqu'il était administré à des doses de 40 à $160 \mathrm{mg}$ par jour. la dose initiale de $120 \mathrm{mg}$ administrée avant l'ajustement des doses suivantes du médicament semble être une stratégie thérapeutique raisonnable.
In 1955, Zollinger and Ellison (1) described the syndrome 1 that now bears their names. They described a triad of ulcer diseases of the upper gastrointestinal tract, a marked increase in gastric acid secretion and non-beta islet cell tumour of the pancreas (1). These tumours, referred to as gastrinomas (because they secrete gastrin, a potent stimulator of gastric acid secretion), are now known to occur in extrapancreatic locations as well (in as many as two-thirds of cases) (2). Peptic symptoms, ulcers and ulcer complications are major sources of morbidity, although since the advent of effective acid-suppressing therapy, the principal threat to life has been malignant invasion by the tumours (3).

Over the years, numerous studies have attempted to establish the best acid-suppressing medical treatment for patients with Zollinger-Ellison syndrome (ZES). Ten years ago, proton pump inhibitors (PPIs) were introduced and the management of patients with gastric acid hypersecretion due to gastrinoma was radically changed. Surgical treatment now concentrates on tumour excision and, in the vast majority of patients, gastrectomy is no longer required to prevent the complications of acid hypersecretion that can be managed pharmacologically.

Omeprazole is well recognized for the treatment of ZES patients $(4,5)$. Intravenous pantoprazole was recently shown to control gastric acid output rapidly and effectively (6). The aim of the present study was to determine the doses of oral pantoprazole needed to manage gastrinoma effectively.

\section{PATIENTS AND METHODS}

Patients: Seven patients with established diagnoses of gastrinoma were included in the study. All seven received the diagnoses during the past decade according to established criteria - elevated serum gastrin levels with an increased gastric acid secretion and positive results with secretin stimulation (7). Tumoral extension was defined by computed tomography (CT) scan or octreotide imaging.

Evaluated parameters: Gastric secretions were collected for four consecutive $15 \mathrm{~min}$ periods through a nasogastric tube inserted in a patient lying on his or her left side. Acid concentration was measured by titration with sodium carbonate to $\mathrm{pH}$ 7.0. Basal acid output (BAO) was measured seven days after the beginning of pantoprazole treatment. It was measured at 08:00, $1 \mathrm{~h}$ before administration of the next dose of pantoprazole.

Peptic symptoms (diarrhea, heartburn, etc) were clinically evaluated weekly either by follow-up visits at the clinic or by telephone.
Drug regimen: Oral pantoprazole was administered at breakfast. Doses of pantoprazole were adjusted to control the peptic symptoms and to keep the BAO between 0.1 and $10 \mathrm{mmol} / \mathrm{h}$.

Patients were started on pantoprazole $80 \mathrm{mg}(2 \times 40 \mathrm{mg}$ tablets). The dose was decreased to $40 \mathrm{mg}$ if the patient demonstrated achlorhydria (BAO less than $0.1 \mathrm{mmol} / \mathrm{h}$ ) or increased to $120 \mathrm{mg}$ (or more) daily if there was evidence of insufficient inhibition (BAO greater than $10 \mathrm{mmol} / \mathrm{h}$ ) or symptomatic deterioration.

\section{RESULTS}

The characteristics and evolution of the patients are summarized in Table 1.

Seven patients (three women and four men) with a mean age of 60.1 years were enrolled in the study. Five patients had sporadic ZES, while the other two had ZES associated with multiple endocrine neoplasia syndrome. None of the patients had prior acid-reducing surgery, but two patients underwent surgical resection (including one unsuccessful Whipple procedure). One patient underwent chemotherapy. The mean duration of disease before the start of pantoprazole treatment was 36.7 months.

All patients were free of peptic symptoms at the beginning of the study. Five of the seven patients were already taking omeprazole (range 60 to $80 \mathrm{mg}$ in either single or multiple doses); one (patient 4) was originally taking lansoprazole; the last patient (patient 5) underwent partial removal of the gastrinoma and was started on oral pantoprazole $40 \mathrm{mg}$ once daily. The mean BAO before the introduction of pantoprazole was $1.84 \mathrm{mmol} / \mathrm{h}$.

For BAO to be adequately controlled and for patients to be symptom free, three patients (patients 1,2 and 4) required a dose of $120 \mathrm{mg} /$ day, while two others (patients 6 and 7) received $80 \mathrm{mg} /$ day. The last two patients required $40 \mathrm{mg}$ once daily (patient 5) and $160 \mathrm{mg}$ once daily (patient 3) of pantoprazole (Figure 1).

\section{DISCUSSION}

Peptic symptoms and complications are the main source of morbidity in patients with ZES. The most common clinical manifestation seen in patients with the syndrome is peptic ulcer, which is present in over $90 \%$ of patients $(2,8)$. Although the symptoms may not differ from those of patients with common peptic ulcer, they may be more persistent and less responsive to therapies that are usually successful in the treatment of common varieties of peptic ulcer. Our results indicate that oral pantoprazole is able to control 
TABLE 1

Characteristics and clinical evolution of patients taking pantoprazole

\begin{tabular}{|c|c|c|}
\hline Patient & $\begin{array}{l}\text { Age, } \\
\text { years (sex) }\end{array}$ & $\begin{array}{l}\text { Medical treatment } \\
\text { and peptic symptoms }\end{array}$ \\
\hline 1 & $69(M)$ & $\begin{array}{l}\text { Patient's (MEN-positive) symptoms were well controlled for four years with omeprazole } 40 \mathrm{mg} \text { in the morning and } 20 \mathrm{mg} \text { in } \\
\text { the evening. Five days after administration of pantoprazole } 80 \mathrm{mg} \text {, diarrhea occurred. Patient was well (BAO } 0.1 \mathrm{mmol} / \mathrm{h} \text { ) } \\
\text { on pantoprazole } 80 \mathrm{mg} \text { in the morning, } 40 \mathrm{mg} \text { in the evening. }\end{array}$ \\
\hline 2 & $72(\mathrm{M})$ & $\begin{array}{l}\text { Patient's symptoms were well controlled for seven years with omeprazole } 60 \mathrm{mg} \text { once daily. After one week on } \\
\text { pantoprazole } 80 \mathrm{mg} \text { once daily, BAO was } 4.6 \mathrm{mmol} / \mathrm{h} \text {, but BAO increased to } 13 \mathrm{mmol} / \mathrm{h} \text { after five months (no symptoms). } \\
\text { His symptoms are now well controlled with pantoprazole } 120 \mathrm{mg} \text { once daily. }\end{array}$ \\
\hline 3 & $63(\mathrm{M})$ & $\begin{array}{l}\text { Patient's (MEN-positive) symptoms were well controlled with omeprazole } 80 \mathrm{mg} \text { once daily for seven years. After three } \\
\text { months on pantoprazole } 120 \mathrm{mg} \text { once daily, diarrhea occurred. He is now well (BAO } 4.6 \mathrm{mmol} / \mathrm{h} \text { ) on pantoprazole } \\
160 \mathrm{mg} \text { once daily. }\end{array}$ \\
\hline 4 & $50(\mathrm{~F})$ & $\begin{array}{l}\text { Patient was well on lansoprazole } 60 \mathrm{mg} \text { once daily for two years. BAO was } 6.2 \mathrm{mmol} / \mathrm{h} \text { following administration of } \\
\text { pantoprazole } 80 \mathrm{mg} \text { once daily; diarrhea occurred four weeks later and was controlled with pantoprazole } 120 \mathrm{mg} \text { once } \\
\text { daily. }\end{array}$ \\
\hline 5 & $50(\mathrm{M})$ & $\begin{array}{l}\text { Following partial tumour resection by Whipple procedure, the patient was administered pantoprazole } 40 \mathrm{mg} \text { once daily. } \\
\text { Symptoms have been well controlled for three years (BAO/year } 1.7,4.6,3.0 \mathrm{mmol} / \mathrm{h} \text { ). }\end{array}$ \\
\hline 6 & $47(\mathrm{~F})$ & $\begin{array}{l}\text { Patient had metastatic disease. Symptoms were well controlled with omeprazole } 20 \mathrm{mg} \text { tid for one year. Patient was well } \\
\text { (BAO } 2.1 \mathrm{mmol} / \mathrm{h} \text { ) on pantoprazole } 40 \mathrm{mg} \text { bid for two months before chemotherapy and octreotide therapy were added. }\end{array}$ \\
\hline 7 & $70(\mathrm{~F})$ & $\begin{array}{l}\text { Patient's symptoms were well controlled with omeprazole } 60 \mathrm{mg} \text { once daily for four months. Patient was well (BAO } \\
0.1 \mathrm{mmol} / \mathrm{h} \text { ) on pantoprazole } 80 \mathrm{mg} \text { once daily for four months before resection of a duodenal gastrinoma. }\end{array}$ \\
\hline
\end{tabular}

BAO Basal acid output; F Female; M Male; MEN Multiple endocrine neoplasia

acid hypersecretion in ZES patients when administered in doses between 40 and $160 \mathrm{mg}$ daily. An initial oral dose of pantoprazole $120 \mathrm{mg}$ once daily given before further adjustment of the drug regimen appears to be a reasonable therapeutic strategy.

The diagnosis of ZES should always be suspected in patients with severe peptic disease or with ulcers in ectopic locations. Most ulcers are found in the first portion of the duodenum, but ulcers associated with gastrinomas may also be found in the second, third or fourth portion(s) of the duodenum, or even in the jejunum. Gastric ulcers are much less frequent. Gastroesophageal reflux disease is also more frequent and often more severe in patients with ZES, and complications such as dysphagia, esophagitis, stricture formation and Barrett's syndrome occur more frequently than was initially thought $(9,10)$.

Another symptom associated with ZES is diarrhea, which may be the only clinical manifestation of the gastrinoma. An increased volume of gastric acid secretion in the upper gastrointestinal tract is the main factor responsible for diarrhea and malabsorption (11). Control of acid hypersecretion alleviates the diarrhea. Steatorrhea, caused by lipase inactivation by increased intraluminal acid in the upper small intestine, can also occur (3).

Surgical excision of all tumours is the main goal of therapy in patients with ZES. CT scan, octreotide scintiscan and echoendoscopy are the most useful diagnostic tests to localize tumours before laparotomy. The tumours are often very small, and when surgery is performed by expert medicosurgical teams, cure is observed in $30 \%$ to $50 \%$ of patients $(3,8,12)$.

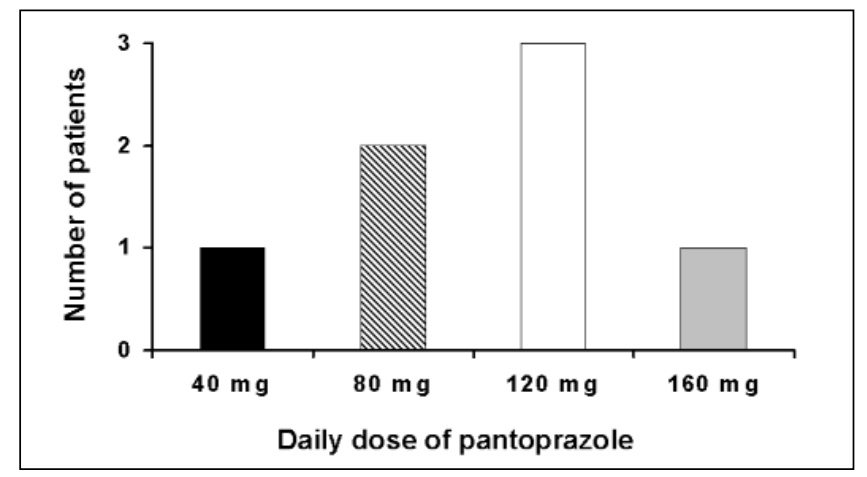

Figure 1) Doses of pantoprazole for the management of patients with Zollinger-Ellison syndrome. The number of patients whose symptoms were controlled successfully by each daily dose of pantoprazole (40 to $160 \mathrm{mg}$ shown on the abscissa) is indicated on the ordinate

Avoiding the complications of hypergastrinemia and hyperchlorhydria is the initial step in treatment. PPIs are the preferred drugs, and treatment must be started as soon as possible when a diagnosis of ZES is suspected. Experience with omeprazole indicates that an initial dose of $60 \mathrm{mg}$ daily is usually recommended $(3-5,7,13)$. Because the relief of heartburn or diarrhea is not a reliable indication of the absence of mucosal injury, the level of acid inhibition must be assessed; this is usually done by measuring the BAO, which should be kept under $10 \mathrm{mmol} / \mathrm{h}$ (14). Compared with $\mathrm{H}_{2}$ receptor antagonists, which are commonly associated with escape phenomenon or drug tachyphylaxis, PPIs seem to offer stable and consistent protection against acid damage to the mucosa, and, in most cases, periodic control 
of BAO every one to two years seems to be adequate. However, the PPI treatment must not be stopped. Interruption of PPI treatment, even for a period as brief as $24 \mathrm{~h}$, can lead to serious peptic complications (perforation, hemorrhage, etc). It is surprising to see patients with untreated ZES who can tolerate major acid hypersecretion with rather few clinical symptoms; this is probably due to the progressive development of the gastric hypersecretion and to the parallel development of compensatory mechanisms (increased secretion of carbonate by pancreas or duodenal glands, etc) (11). However, after pharmacological normalization of gastric acid secretion, the defence mechanisms probably rapidly regress and, in our experience (15), the patients cannot tolerate any further exposure to the large acid load that can promptly resume after PPI cessation. In our experience, PPI treatment does not seem to modify the gastrin response to secretin administration (Poitras, unpublished data), and interruption of PPI treatment is not recommended for the purpose of medical investigation. Patients should be told to maintain rigid compliance with the drug treatment.

Pantoprazole is a substituted benzimidazole that exerts its pharmacodynamic actions by binding to the proton

\section{REFERENCES}

1. Zollinger RM, Ellison EC. Primary peptic ulcerations of the jejunum associated with islet-cell tumors of the pancreas. Ann Surg 1955;142:709-28.

2. Meko JB, Norton JA. Management of patients with Zollinger-Ellison syndrome. Annu Rev Med 1995;46:395-411.

3. Feldman M, Scharschmidt BF, Sleisenger M, Zorab R, eds. Sleisenger and Fordtran's Gastrointestinal and Liver Disease: Pathophysiology/Diagnosis/Management, 6th edn. Philadelphia: WB Saunders, 1998:679-92.

4. McArthur KE, Collen MJ, Maton PN, et al. Omeprazole: effective, convenient therapy for Zollinger-Ellison syndrome. Gastroenterology 1985;88:939-44.

5. Maton PN, Lack E, McArthur KE, et al. Effects of long term omeprazole on gastric acid secretion and mucosal histology in patients with Zollinger-Ellison syndrome. Gastroenterology 1988;94:A288. (Abst)

6. Lew EA, Pisegna JR, Starr JA, et al. Intravenous pantoprazole rapidly controls gastric acid hypersecretion in patients with Zollinger-Ellison syndrome. Gastroenterology 2000;118:696-704.

7. Metz DC, Pisegna JR, Fishbeyn VA, Benya RV, Jensen RV. The control of gastric acid hypersecretion in the management of patients with Zollinger-Ellison syndrome. World J Surg 1993;17:468-80.

8. Orloff SL, Debas HT. Advances in the management of patients with Zollinger-Ellison syndrome. Surg Clin North Am 1995;75:511-24.

9. Bondeson AG, Bondeson L, Thompson NW. Stricture and perforation of the esophagus: overlooked threats in the ZollingerEllison syndrome. World J Surg 1990;14:361-4. pump $\left(\mathrm{H}^{+} / \mathrm{K}^{+}\right.$ATPase $)$in the parietal cells. It is known to have equivalent efficacy whether administered intravenously or orally (16), and has an oral bioavailability of approximately $77 \%$. Pantoprazole is as effective as other PPIs in the healing of esophagitis, and gastric and duodenal ulcers, and as a part of the triple-drug regimens used to eradicate Helicobacter pylori (17). It is well tolerated and has no known interactions with other drugs. A recent study evaluated the safety and efficacy of intravenous pantoprazole in patients with established ZES and identified a maintenance regimen to avoid the need for continuous acid output monitoring during use (6). The present study established that oral pantoprazole $120 \mathrm{mg} /$ day was the appropriate maintenance dose for most ZES patients. One recent study from South Africa, published as an abstract (18), confirmed that long term administration of 120 or $160 \mathrm{mg}$ of oral pantoprazole was effective and safe for the management of ZES patients.

ACKNOWLEDGEMENTS: This study was supported by a grant-in-aid from Solvay Pharma Clinical Inc, Ontario, Canada and Byk Canada Inc, Ontario, Canada.
10. Miller LS, Vinayek R, Frucht H, Gardner JD, Jensen RT, Maton PN. Reflux esophagitis in patients with Zollinger-Ellison syndrome. Gastroenterology 1990;98:341-6.

11. Modigliani R, Bernier JJ, Matuchanski C, Rambaud JC. Intestinal water and electrolyte transport in man under the effect of exogenous hormones of the gut and in patients with endocrine tumors of the pancreas. In: Glass GBJ, ed. Progress in Gastroenterology, vol III. New York: Grune and Stratton Inc, 1977:245-319.

12. Norton JA. Gastrinoma: advances in localization and treatment. Surg Oncol Clin N Am 1998;7:845-61.

13. Wolfe M, Sachs G. Acid suppression: optimizing therapy for gastroduodenal ulcer healing, gastroesophageal reflux disease, and stress-related erosive syndrome. Gastroenterology 2000;118:S9-31.

14. Raufman JP, Collins SM, Pandol SJ, et al. Reliability of symptoms in assessing control of gastric acid secretion in patients with ZollingerEllison syndrome. Gastroenterology 1983;84:108-13.

15. Poitras P, Tassé D. Management of patients with Zollinger-Ellison syndrome. Can J Gastroenterol 1989;3(Suppl A):77A-83A.

16. Hartmann M, Ehrlich A, Fuder H, et al. Equipotent inhibition of gastric acid secretion by equal doses of oral or intravenous pantoprazole. Aliment Pharmacol Ther 1998;12:1027-32.

17. Welage LS, Berardi RR. Evaluation of omeprazole, lansoprazole, pantoprazole and rabeprazole in the treatment of acid-related diseases. J Am Pharm Assoc (Wash) 2000;40:52-62.

18. Bornman P, Radebold K, De Baere HS, et al. Efficacious long-term maintenance therapy with pantoprazole in patients with ZollingerEllison syndrome. Gastroenterology 2001;120:A613. (Abst) 


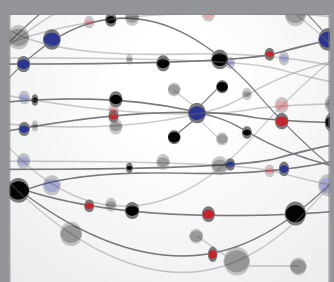

The Scientific World Journal
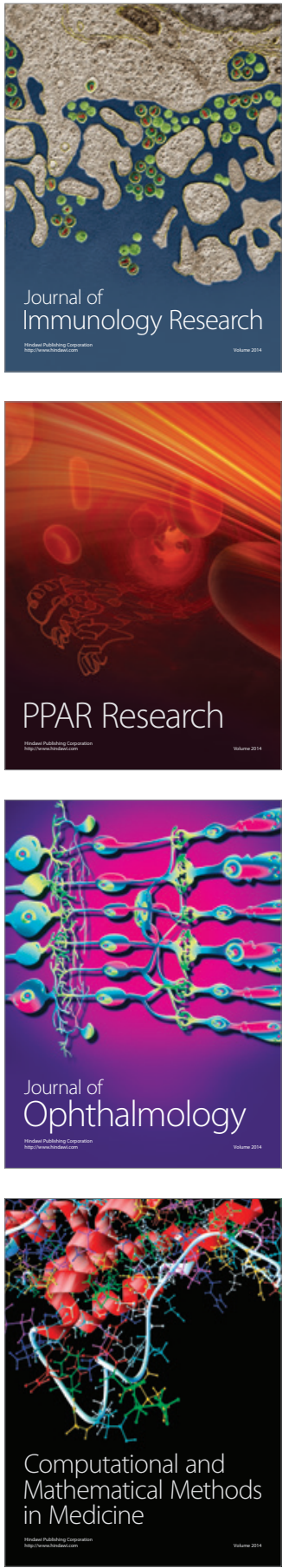

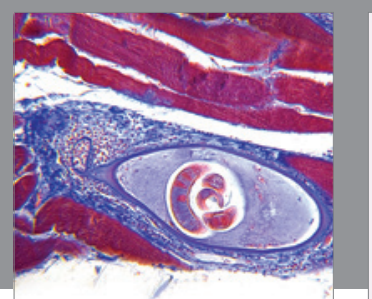

Gastroenterology Research and Practice

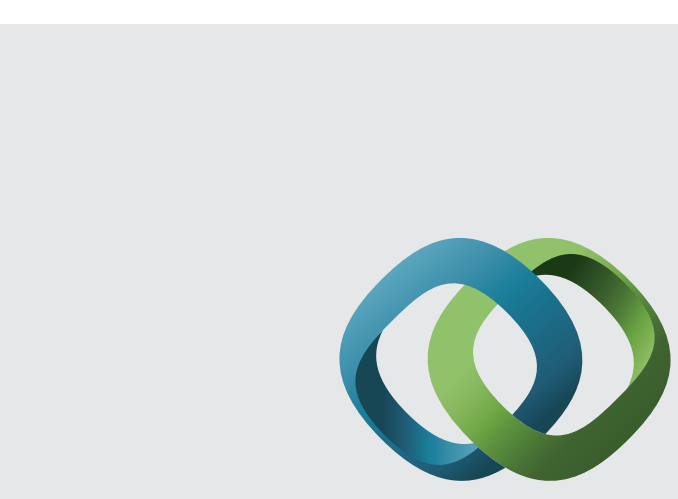

\section{Hindawi}

Submit your manuscripts at

http://www.hindawi.com
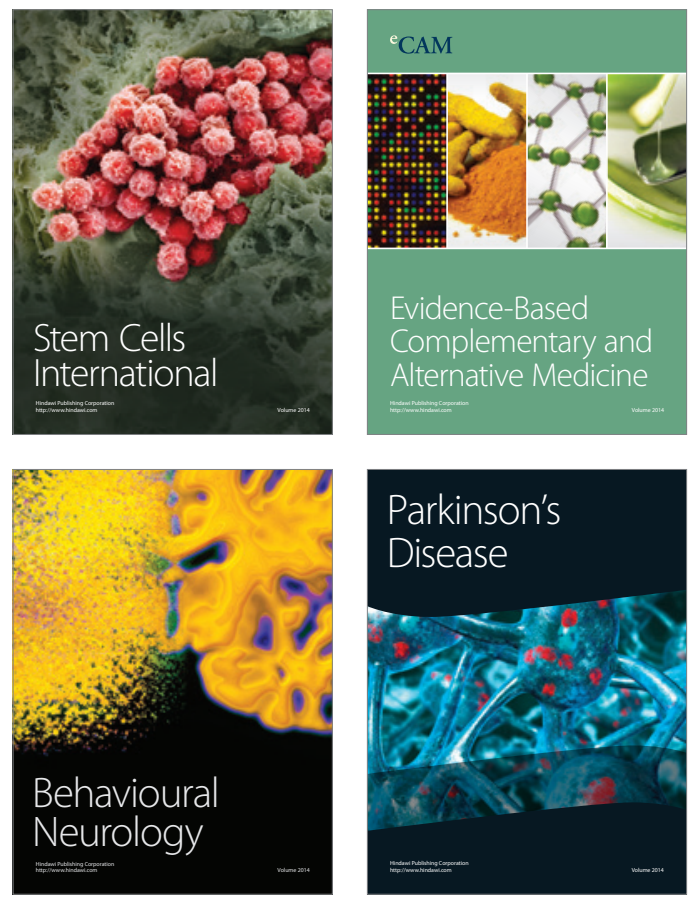
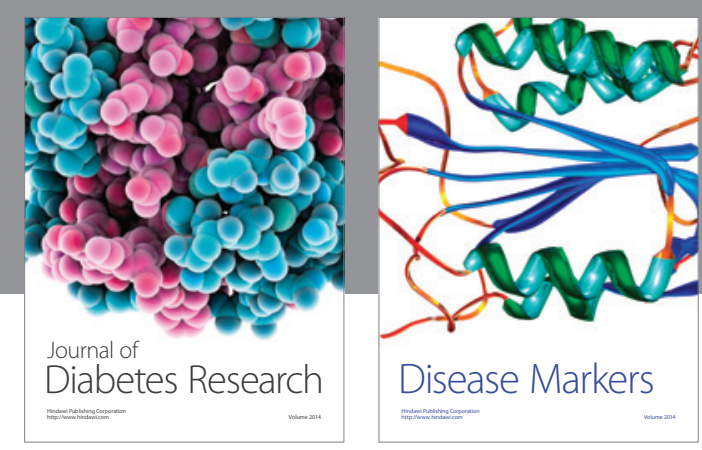

Disease Markers
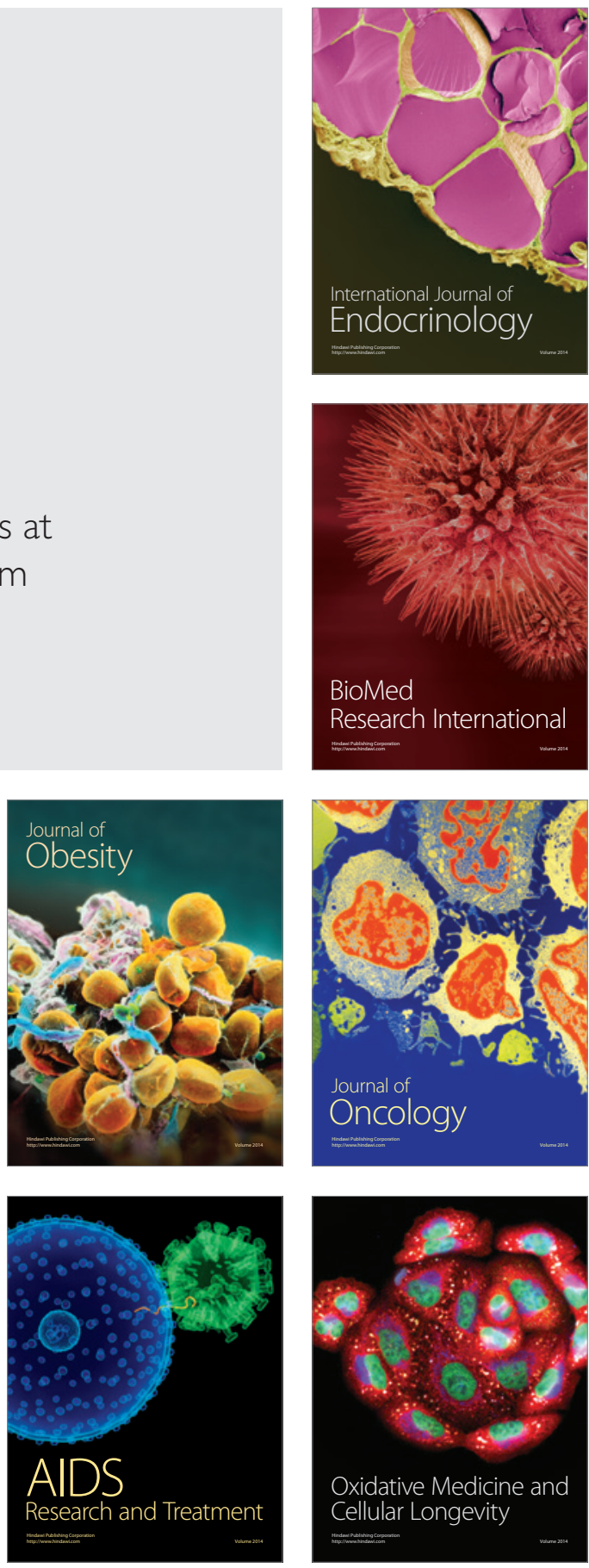